\title{
EFEKTIVITAS LKS BERBASIS PENDEKATAN OPEN-ENDED TERHADAP KEMAMPUAN PEMECAHAN MASALAH MATEMATIS SISWA SMP
}

\author{
Nur Fitriyana ${ }^{1}$, Lucy Asri Purwasi ${ }^{2}$ \\ ${ }^{1,2}$ STKIP PGRI Lubuklinggau \\ E-mail: nurfi3ana@ gmail.com $^{1)}$ \\ asripurwasi@gmail.com $^{2)}$
}

Received 20 October 2018; Received in revised form 16 November 2018; Accepted 23 December 2018

\begin{abstract}
This study aims to determine the effectiveness of worksheets based on an open-ended approach to students' mathematical problem solving abilities. Subjects in the study were eighth grade public and private junior high school students in Lubuklinggau City who were from 3 schools. Each school is SMP Negeri 1 Lubuklinggau totaling 33 students, SMP Negeri 14 Lubuklinggau totaling 29 students and SMP PGRI 3 Lubuklinggau totaling 14 students. Data collection techniques in this study are test techniques. the test used in the study is a description test which is compiled based on indicators of mathematical problem solving abilities. The data analysis technique used in this study is one sample t-test with the help of SPSS Version 24 program.The data analysis $t$-test students' mathematical problem solving capabilities of three schools only SMP Negeri 1 Lubuklinggau which show significantly less than equal to 61 ( $\mu$ o $\leq$ 61). SMP Negeri 14 Kota Lubuklinggau and SMP PGRI 3 Lubuklinggau showed that the average mathematical problem-solving ability of students after using LKS based on open-ended was significantly more than 61 ( $\mu$ o > 61). Of the two schools that have been represented, it can be concluded that the implementation of Open-ended worksheets is effective to use.
\end{abstract}

Keywords: open-ended; problem solving abilities; student worksheet.

\section{PENDAHULUAN}

Lembar kerja siswa (LKS) adalah sumber belajar penunjang yang dapat meningkatkan pemahaman siswa mengenai materi yang harus mereka kuasai. LKS merupakan alat bantu untuk menyampaikan pesan kepada siswa yang digunakan oleh guru dalam proses pembelajaran. Menurut Evalida dan Hastarudin (2016) LKS dalam pembelajaran matematika merupakan salah satu sarana yang dapat digunakan guru matematika untuk membantu siswa untuk meningkatkan kreativitas siswa dalam memecahkan masalah matematika. LKS juga merupakan media pembelajaran yang dapat digunakan secara bersamaan dengan sumber belajar yang lain. Agar LKS dapat memberikan dampak yang nyata untuk mempermudah siswa belajar, LKS perlu disusun atau dibuat dengan mempertimbangkan berbagai macam pendekatan pembelajaran. Menurut Suyatno (2009:62) pendekatan open-ended artinya pembelajaran yang menyajikan permasalahan dengan berbagai cara. Selanjutnya menurut Tim Pengembang UPI (2009) open-ended problems diartikan sebagai suatu masalah yang diformulasikan sedemikian hingga memiliki kemungkinan variasi jawaban benar baik dari metode, cara atau pendekatan yang berbeda-beda dalam upaya memperoleh jawaban yang benar. Pendekatan open-ended dilandasi oleh teori belajar kontruktivisme yang lebih mengutamakan proses daripada hasil. Dalam proses pembelajaran siswa dihadapkan pada suatu masalah di mana siswa dituntut untuk dapat mengembangkan metode, cara, atau pendekatan yang berbeda-beda dalam 
upaya memperolah jawaban yang benar (Lestari \& Yudhanegara, 2015:41)

Penggunaan LKS berbasis pendekatan open-ended mengandung potensi yang sangat besar untuk meningkatkan kualitas pembelajaran dan kemampuan berpikir matematika tingkat tinggi (Tim Pengembang UPI, 2009). Oleh sebab itu, instrumen ini sangat memungkinkan dapat melatih kemampuan berpikir kreatif siswa dalam memecahkan masalah. Dengan instrumen soal-soal yang tidak biasa siswa diberi kebebasan dalam menjawab soal dengan cara siswa sendiri berdasarkan pemahaman siswa. Mina (2006:6) mengemukakan bahwa openended memberikan keleluasaan kepada siswa untuk berpikir secara aktif dan kreatif dalam melakukan pemecahan masalah dan sangat menghargai keragaman berpikir yang mungkin timbul selama proses pemecahan masalahnya

Epstein (Wijaya, 2012) aspek keterbukaan pada masalah terbuka dapat diklasifikasikan ke dalam tiga tipe, yaitu: 1) terbuka proses penyelesaiannya, yakni soal itu memiliki beragam cara penyelesaian. Jenis Soal semacam ini masih memungkinkan memiliki satu solusi tunggal, 2) terbuka hasil akhirnya, yakni soal itu memiliki banyak jawab yang benar, dan 3) terbuka pengembangan lanjutannya, yakni ketika siswa telah menyelesaikan suatu masalah, selanjutnya mereka dapat mengembangkan soal baru dengan mengubah syarat atau kondisi pada soal yang telah diselesaikan.

Penelitian mengenai pengembangan LKS dan efekktivitas pendekatan open-ended telah dilakukan dengan berbagai fokus dan kesimpulan penelitian, sehingga hal ini dijadikan tolak ukur sebagai penelitian yang relevan. Pada Penelitian Kasmawati, Yenti \& Zulmardi (2014) menggunakan pendekatan open-ended dalam mengembangkan LKS namun aspek yang digunakan pemahaman konsep siswa pada materi segitiga dan segiempat. Pada Penelitian Anwar, Johar \& Juandi (2015) menggunakan pendekatan open-ended dalam mengembangkan perangkat pembelajaran dan aspek yang digunakan kemampuan berpikir kreatif siswa.

Selanjutnya pada penelitian Evalida \& Hastarudin (2016) dengan mengembangkan lembar kerja siswa berbasis pendekatan open-ended dalam meningkatkan kemampuan pemecahan masalah matematika dan berpikir kreatif siswa pada materi kubus dan balok. Pada penelitian Puspitasari, Lambertus, \& Samparadja (2014) menggunakan efektivitas pendekatan open-ended dalam meningkatkan kemampuan pemecahan masalah matematika. Berdasarkan penelitian yang telah dilakukan sehingga menjadi rujukan dalam melakukan penelitian pengembangan LKS berbasis pendekatan open-ended dengan aspek yang digunakan adalah pemecahan masalah pada materi Sistem Persamaan Linear Dua Variabel (SPLDV) dan melihat efektivitas produk LKS dalam meningkatkan kemampuan pemecahan masalah matematis siswa.

Berdasarkan hasil survey dan wawancara dengan guru matematika dan siswa kelas VIII Sekolah Menengah Pertama di Kota Lubuklinggau, diketahui bahwa masih banyak permasalahan-permasalahan yang ditemui dalam proses kegiatan pembelajaran. Salah satu permasalahan yang dijumpai adalah belum ada bahan ajar berupa LKS dengan pendekatan open-ended yang bisa membantu guru dalam membelajarkan siswa untuk menuntut satu jawaban yang benar menjadi permasalahan terbuka (openended problems) sehingga kemampuan

\section{6 | AKSIOMA}

Jurnal Pendidikan Matematika FKIP Univ. Muhammadiyah Metro 
pemecahan masalah matematis siswa tidak dapat berkembang dengan baik. Selain itu. Masih jarang ditemukan bahan ajar dikembangkan secara mandiri oleh guru, bahan ajar yang digunakan dalam proses pembelajaran di kelas yaitu langsung dari penerbit baik itu berupa buku ajar maupun LKS.

Hal ini seperti dikemukakan Mursalin (2014), bahwa ketersediaan buku ajar seperti tersebut di atas sangat jarang ditemukan di sekolah, apalagi dikembangkan oleh guru. Guru cenderung menggunakan buku paket yang telah ada tanpa ada usaha untuk membuat atau mengembangkan yang lainnya. Pengembangan buku ajar yang mampu melibatkan siswa untuk aktif dalam setiap kegiatan pebelajaran sangat jarang ditemukan di sekolah. Sekolah terutama guru hanya menggunakan bahan ajar apa adanya sehingga semangat kreativitas siswa sangat rendah.

Pentingnya kemampuan pemecahan masalah tersebut untuk selalu dikembangkan dalam proses pembelajaran di kelas didukung juga menurut Pehkonen (Setiawan \& Harta, 2014) alasan pentingnya pemecahan masalah diberikan karena pemecahan masalah: (1) dapat mengembangkan keterampilan kognitif, (2) dapat meningkatkan kreativitas, (3) merupakan bagian dari proses aplikasi matematika, (4) dapat memotivasi siswa untuk belajar matematika. Menururt Arifin (Amir, 2015) dalam perspektif pendidikan khusunya dalam pendidikan matematika, paradigma yang memunculkan kemampuan pemecahan masalah melalui strategi-strategi yang tepat haruslah dipertahankan. Namun di Indonesia paradigma ini masih belum banyak memikat perhatian para guru dalam mengelola proses pembelajaran matematika. Sehingga perlu dilakukan inovasi dalam proses pembelajaran melalui implementasi dan pengembangan LKS berbasis pendekatan open-ended dengan menyajikan masalah terbuka dan non-rutin untuk memberikan kesempatan seluas-luasnya pada siswa agar aktivitas pemecahan masalah dan pemikiran matematisnya dapat berkembang.

Adapun keunggulan dengan pemberian soal-soal open-ended menurut Selain itu Takahashi (Mustikasari, Zulkardi \& Aisyah, 2010), menyebutkan beberapa keunggulan berkenaan dengan hal ini adalah 1) Siswa mengambil bagian lebih aktif dalam pembelajaran, dan sering menyatakan ide-ide mereka; 2) Siswa mempunyai lebih banyak peluang menggunakan pengetahuan dan keterampilan matematis mereka; 3) Siswa dengan kemampuan rendah bisa memberikan reaksi terhadap masalah dengan beberapa cara signifikan dari milik mereka sendiri; 4) Mendorong Siswa untuk memberikan bukti; 5) siswa mempunyai pengalaman kaya dan senang atas penemuan mereka dan menerima persetujuan temannya.

Keunggulan dari pemberian soal open-ended dalam pembelajaran matematika adalah kemampuan berpikir matematika siswa dapat berkembang secara maksimal, melalui berbagai strategi dan cara yang diyakininya dalam menyelesaikan masalah,sehingga membantu perkembangan aktivitas dan kreativitas berpikir siswa (Mustikasari, Zulkardi, \& Aisyah, 2010).

Karakteristik LKS berbasis pendekatan open-ended yang disusun berdasarkan dua tipe keterbukaannya yaitu meliputi masalah terbuka proses penyelesaiannya dan terbuka hasil akhirnya. Adapun tujuan dalam penelitian ini adalah untuk mengetahui bagaimanakah efektivitas LKS berbasis pendekatan open-ended terhadap kemampuan pemecahan masalah 
matematis siswa Kelas VIII SMP di Kota Lubuklinggau.

\section{METODE PENELITIAN}

Metode penelitian adalah cara yang digunakan oleh peneliti dalam mengumpulkan data penelitiannya (Arikunto, 2010). Metode yang digunakan dalam penelitian ini adalah quasi experiment atau eksperimen semu.Subjek dalam penelitian adalah siswa SMP Negeri dan Swasta kelas VIII di Kota Lubuklinggau yang dipilih sebanyak 3 sekolah. Adapun 3 sekolah yang menjadi subjek dan menerima perlakuan dalam penelitian pada Tabel 1 .

Tabel 1 Subjek Penelitian

\begin{tabular}{lcc}
\hline No & Nama Sekolah & Kategori \\
\hline 1 & SMP Negeri 1 Kota & Tinggi \\
Lubuklinggau & (A) \\
2 & SMP Negeri 14 & Sedang \\
Kota Lubuklinggau & $(B)$ \\
3 & SMP PGRI 3 Kota & Sedang \\
Lubuklinggau & (B) \\
\hline \multicolumn{4}{c}{ Pengambilan sampel } & dilakukan \\
secara stratefikasi random sampling, \\
dimana setiap tingkatan sekolah \\
ditentukan 1 kelas sebagai subjek \\
penelitian. Adapun kelas yang terpilih \\
sebagai sampel dalam penelitian adalah \\
1) SMP Negeri 1 Kota Lubuklinggau \\
kelas yang terpilih adalah kelas VIII.5 \\
yang berjumlah 33 siswa, 2) SMP Negeri \\
14 Kota Lubuklinggau kelas yang \\
terpilih adalah kelas VIII.4 yang \\
berjumlah 29 siswa, dan 3) SMP PGRI \\
3Kota Lubuklinggauadalah kelas VIII \\
yang berjumlah 14 siswa. \\
Teknik pengumpulan data dalam \\
penelitian ini adalah teknik tes. Menurut \\
Arikunto (2010) tes adalah serentetan \\
pertanyaan atau latihan serta alat lain \\
yang digunakan untuk mengukur \\
keterampilan, pengetahuan intelegensi, \\
kemampuan atau bakat yang dimiliki \\
oleh individu atau kelompok.Tes yang
\end{tabular}

digunakan dalam penelitian adala tes uraian yang disusun berdasarkan indikator kemampuan pemecahan masalah matematis yang berjumlah 5 soal uraian, sesuai indikator pemecahan masalah dari Polya (Suci \& Rosyidi, 2012) yaitu, 1) memahami masalah, 2) merencanakan penyelesaian, 3) menyelesaikan rencana penyelesaian dan 4) memeriksa kembali. Teknik pengumpulan data melalui teknik penskoran kemampuan pemecahan matematis siswa. Teknik analisis data yang digunakan dalam penelitian ini adalah uji-t sepihak atau uji one sample $t$-test dengan berbantuan program SPSS versi 24.

\section{HASIL PENELITIAN DAN PEMBAHASAN}

Uji efektivitas LKS berbasis pendekatan open-ended melalui uji One sample t-testatau uji-t sepihak. Uji keefektifan ini bertujuan untuk mengetahui efektif tidaknya pembelajaran dengan LKS berbasis pendekatan open-ended pada aspek kemampuan pemecahan masalah matematis. Sebelum dilakukan analisis uji-t maka terlebih dahulu dilakukan uji prasyarat yaitu uji normalitas berbantuan program SPSS versi 24 terhadap tes kemampuan pemecahan masalah matematis siswa (KPMM) pada ketiga sekolah.

\section{Analisis Uji Normalitas Tes KPMM}

Adapun bentuk hipotesis untuk uji normalitas adalah sebagai berikut:

$\mathrm{H}_{0}$ : sampel berdistribusi normal $\mathrm{H}_{\mathrm{a}}$ : sampel tidak berdistribusi normal

Menurut Gunawan (2013) dalam pengujian hipotesis, kriteria untuk menolak atau menerima $\mathrm{H}_{0}$ pada uji normalitas digunakan pedoman sebagai berikut:

\section{8 | AKSIOMA}

Jurnal Pendidikan Matematika FKIP Univ. Muhammadiyah Metro 
1. Tetapkan taraf signifikansi uji, $\alpha=$ 0,05 .

2. Bandingkan $p$ dengan taraf signifikansi yang diperoleh.

3. Jika Sig $<\alpha$, maka $\mathrm{H}_{0}$ ditolak dan Jika $\operatorname{Sig} \geq \alpha$, maka $\mathrm{H}_{0}$ diterima.

\section{Analisis Uji Normalitas KPMM di SMP Negeri 1 Kota Kota Lubuklinggau}

Hasil analisis uji normalitas kemampuan pemecahan masalah matematis siswa di SMP Negeri 1 Kota Lubuklinggau dapat dilihat pada tabel 2 berikut.

Tabel 2. Uji Normalitas KPMM

\begin{tabular}{lccc}
\hline & \multicolumn{4}{c}{ Kolmogorov-Smirnov $^{\mathrm{a}}$} \\
\cline { 2 - 4 } & Statistic & df & Sig. \\
\hline KPMM &, 102 & 33 &, $200^{*}$ \\
\hline \multicolumn{3}{c}{ Berdasarkan Tabel 2} & nilai Sig \\
$(0,200) \geq$ & 0,05 maka Ho & diterima, \\
artinya sampel berdistribusi normal.
\end{tabular}

\section{Analisis Uji Normalitas KPMM di SMP Negeri 14 Kota Kota Lubuklinggau}

Hasil analisis uji normalitas kemampuan pemecahan masalah matematis siswa di SMP Negeri 14 Kota Lubuklinggau dapat dilihat pada tabel 3 berikut.

Tabel 3 Uji Normalitas KPMM

\begin{tabular}{cccc}
\hline & \multicolumn{3}{c}{ Kolmogorov-Smirnov } \\
\cline { 2 - 4 } & Statistic & df & Sig. \\
\hline KPMM &, 102 & 29 &, $200^{*}$ \\
\hline
\end{tabular}

Berdasarkan tabel 3 nilai $\mathrm{Sig}$ $(0,200) \geq 0,05$ maka Ho diterima, artinya sampel matematis berdistribusi normal.

\section{Analisis Uji Normalitas KPMM di SMP PGRI 3 Kota Kota Lubuklinggau}

Hasil analisis uji normalitas kemampuan pemecahan masalah matematis siswa di SMP PGRI 3 Kota Lubuklinggau dapat dilihat pada tabel 4 berikut.
Tabel 4. Uji Normalitas KPMM

\begin{tabular}{cccc}
\hline & \multicolumn{3}{c}{ Kolmogorov-Smirnov } \\
\cline { 2 - 4 } & Statistic & df & Sig. \\
\hline KMPM &, 203 & 14 &, 121 \\
\hline
\end{tabular}

Berdasarkan Tabel 4 nilai Sig $(0,121) \geq 0,05$ maka Ho diterima, artinya sampel berdistribusi normal.

\section{Analisis Uji-t Kemampuan} Pemecahan Masalah Matematis Siswa

Bentuk hipotesis untuk uji-t adalah sebagai berikut:

$\mathrm{H}_{0}$ : Rata-rata kemampuan pemecahan masalah matematis siswa setelah menggunakan LKS Berbasis openended secara signifikan kurang dari atau sama dengan dari 61 ( $\mu o \leq$ 61).

$\mathrm{H}_{\mathrm{a}}$ : Rata-rata kemampuan pemecahan masalah matematis siswa setelah menggunakan LKS Berbasis openended secara signifikan lebih dari $61(\mu o>61)$.

Menurut Gunawan (2013) dalam pengujian hipotesis uji-t, kriteria untuk menolak atau menerima $\mathrm{H}_{0}$ digunakan pedoman sebagai berikut:

1. Tetapkan taraf signifikansi uji, $\alpha=$ 0,05 .

2. Bandingkan $p$ dengan taraf signifikansi yang diperoleh.

3. Jika Sig $<\alpha$, maka $\mathrm{H}_{0}$ ditolak dan Jika $\operatorname{Sig} \geq \alpha$, maka $\mathrm{H}_{0}$ diterima.

\section{Analisis Uji-t KPMM di SMP Negeri 1 Kota Lubuklinggau \\ Hasil analisis uji-t sepihak kemampuan pemecahan masalah matematis siswa di SMP Negeri 1 Kota Lubuklinggau dapat dilihat pada Tabel 5.}


ISSN 2089-8703 (Print) Vol. 7, No. 3 (2018) 425-433

ISSN 2442-5419 (Online)

Tabel 5 Uji-t KPMM

Test Value $=33$

\begin{tabular}{lcrr} 
& $\mathrm{t}$ & $\mathrm{df}$ & Sig. (2-tailed) \\
\hline KPMM & 1,486 & 32 &, 147 \\
\hline
\end{tabular}

Berdasarkan Tabel 5 nilai $\mathrm{Sig}$ $(0,147) \geq(0,05)$ maka $\mathrm{H}_{0}$ diterima, artinya rata-rata kemampuan pemecahan masalah matematis siswa SMP Negeri 1 Kota Lubuklinggau setelah menggunakan LKS berbasis open-ended secara signifikan kurang dari atau sama dengan $61(\mu o \leq 61)$.

\section{Analisis Uji-t KPMM di SMP Negeri 14 Kota Kota Lubuklinggau}

Hasil analisis uji-t sepihak kemampuan pemecahan masalah matematis siswa di SMP Negeri 14 Kota Lubuklinggau dapat dilihat pada tabel 6 berikut.

$\frac{\text { Tabel } 6 \text { Uji-t KPMM }}{\text { Test Value }=29}$

\begin{tabular}{|c|c|c|c|}
\hline & $\mathrm{t}$ & $\mathrm{df}$ & Sig. (2-tailed) \\
\hline KPMM & 2,587 & 28 & .015 \\
\hline
\end{tabular}
$(0,015)<(0,05)$ maka $\mathrm{H}_{0}$ ditolak, artinya rata-rata kemampuan pemecahan masalah matematis siswa SMP Negeri 14 Lubuklinggau setelah menggunakan LKS berbasis pendekatan open-ended secara signifikan lebih 61 ( $\mu$ o > 61).

\section{Analisis Uji-t KPMM SMP PGRI 3 Kota Lubuklinggau}

Hasil analisis uji-t sepihak kemampuan pemecahan masalah matematis siswa di SMP PGRI 3 Kota Lubuklinggau dapat dilihat pada tabel 7 berikut.

Tabel 7 Uji-t KPMM

$$
\text { Test Value }=14
$$

\begin{tabular}{cccr} 
& $\mathrm{t}$ & $\mathrm{df}$ & \multicolumn{1}{c}{ Sig. (2-tailed) } \\
\hline KMPM & 12,867 & 13 &, 000 \\
\hline
\end{tabular}

Berdasarkan Tabel 7 nilai Sig $(0,000)<(0,05)$ maka Ho ditolak, artinya rata-rata kemampuan pemecahan masalah matematis siswa SMP PGRI 3 Kota Lubuklinggau setelah menggunakan LKS berbasis pendekatan open-ended secara signifikan lebih dari $61(\mu o>$ 61).

Tes kemampuan pemecahan masalah matematis siswa diberikan setelah siswa memperoleh pembelajaran dengan LKS berbasis pendekatan openended. Materi yang dibahas adalah materi sistem persamaan linear dua variabel (SPLDV). Terpilihnya materi ini berdasarkan pertimbangan melalui analisis kesulitan dan kesalahan yang sering dilakukan oleh siswa dalam belajar matematika. Selain itu, bedasarkan analisis awal, analisis siswa, analisis tugas, analisis konsep dan analisis tujuan pembelajaran serta wawancara yang dilakukan pada guru matematika di SMP Kota Lubuklinggau pada saat melakukan tahap define dalam pengembangan LKS berbasis pendekatan open-ended.

Adapun tampilan LKS yang biasa digunakan sebagai pendukung dalam proses pembelajaran yaitu LKS hanya menyajikan soal-soal pemahaman yang dengan indikator yaitu soal pemahaman (C2) dan aplikasi (C3) yang bersifat rutin sehingga hal ini tidak melatih kemampuan pemecahan masalah siswa. Siswa terbiasa menyelesaikan soal-soal yang bersifat monoton dan prosedural, sehingga hal ini kurang membantu perkembangan aktivitas dan kreatifitas berpikir siswa pada saat proses pembelajaran. 


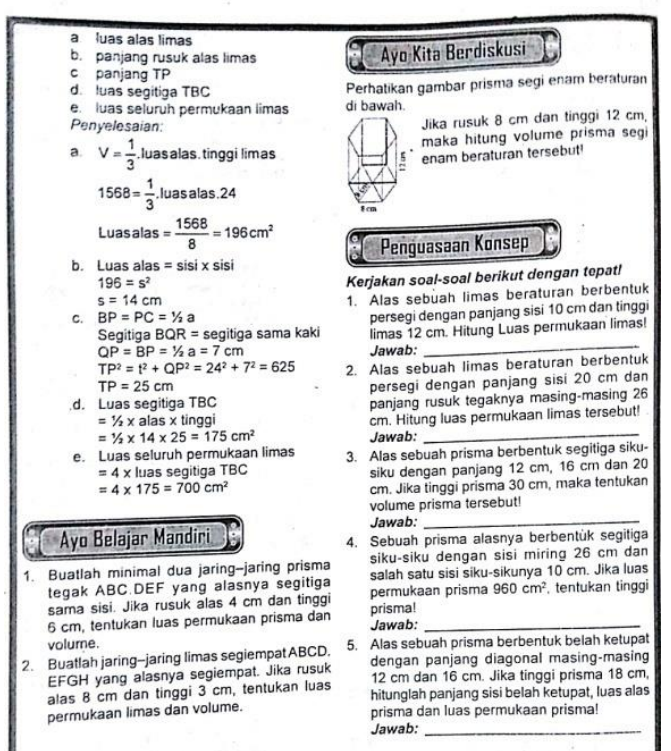

Gambar 1 LKS yang biasa digunakan

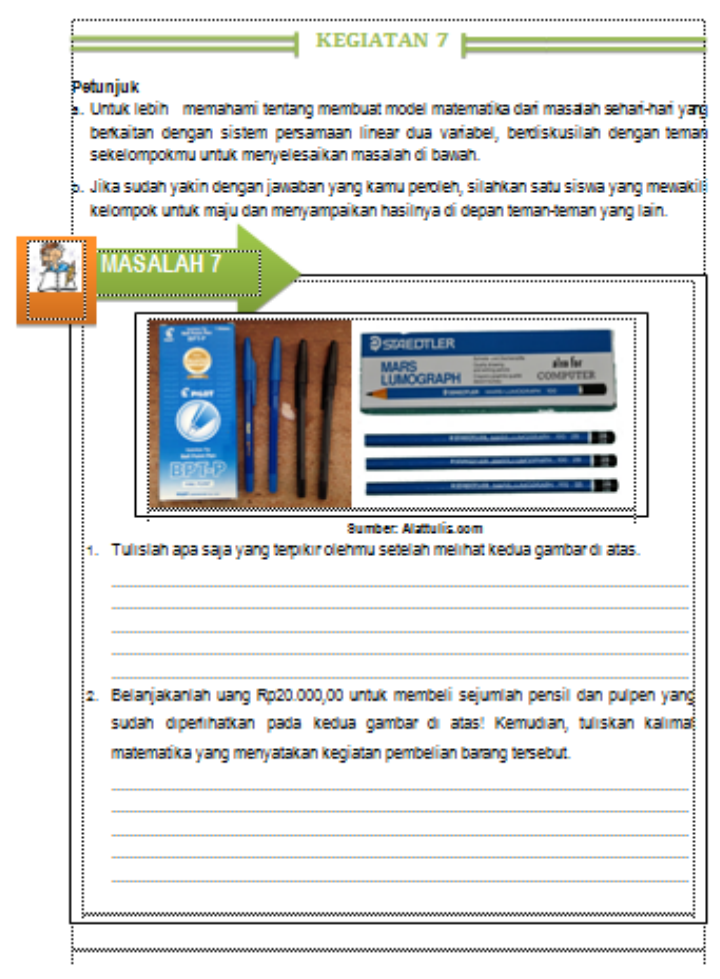

Gambar 2 LKS yang dikembangkan

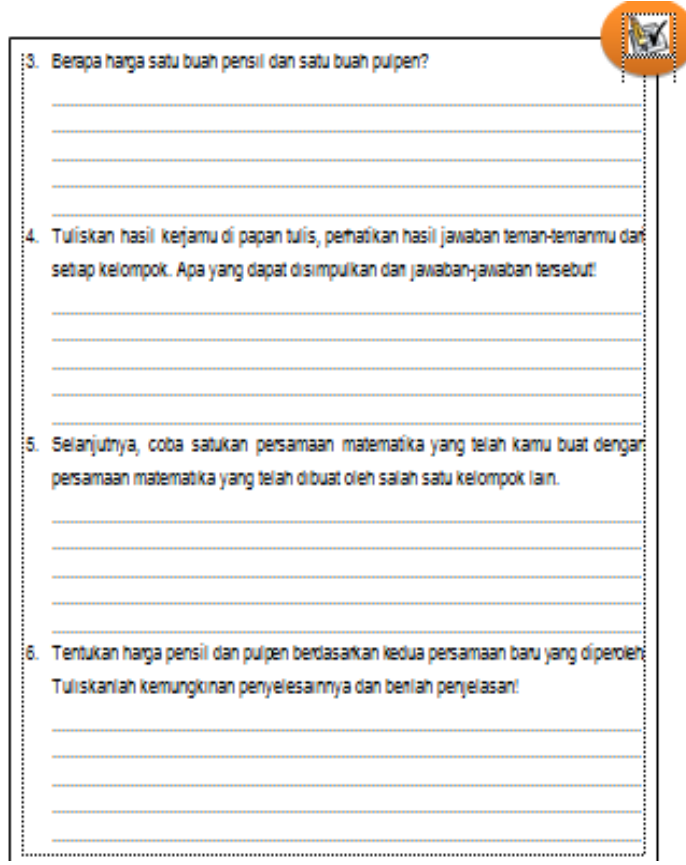

Gambar 3 LKS yang dikembangkan

LKS yang dikembangkan menyajikan kegiatan-kegiatan yang memuat masalah-masalah terbuka melalui langkah kerja yang sistematis. Sehingga siswa dapat terarah dan bertahap dalam menyelesaikannya. Implementasi LKS berbasis pendekatan open-ended dilakukan pada saat LKS sudah dinyatakan valid, praktis dan efektif untuk mengoptimalkan kemampuan pemecahan masalah matematis siswa melalui penyajian soalsoal terbuka pada setiap tahapan kegiatan yang diberikan pada LKS.

Dari hasil analisis data uji-t kemampuan pemecahan masalah matematis siswa dari tiga sekolah menunjukkan: 1) SMP Negeri 1 Kota Lubuklinggau nilai signifikan kurang dari atau sama dengan $61 \quad(\mu o \leq 61)$ artinya, belum efektifnya proses pembelajaran melalui implementasi LKS berbasis pendekatan open-ended pada aspek kemampuan pemecahan masalah matematis siswa, 2) SMP Negeri 14 Kota Lubuklinggau nilai signifikansi lebih dari $61(\mu o>61)$. dan 3) SMP PGRI 3 Lubuklinggau nilai signifikansi 
lebih dari $61(\mu o>61)$ artinya, sudah efektifnya proses pembelajaran melalui implementasi LKS berbasis pendekatan open-ended pada aspek kemampuan pemecahan masalah matematis siswa. Dari dua sekolah yang sudah terwakili dapat disimpulkan bahwa implementasi LKS berbasis open-ended sudah efektif digunakan dalam proses pembelajaran. Berdasarkan penelitian yang dilakukan oleh Mayasari (2014) menunjukkan bahwa bahan ajar yang dikembangkan berbasis pendekatan open-ended efektif dalam meningkatkan kemampuan pemecahan matematika siswa dengan nilai 4,15. Selanjutnya berdasarkan penelitian Evalida \& Hastarudin (2016) keefektifan lembar kerja siswa yang dikembangkan berbasis pendekatan open-ended untuk meningkatkan kemampuan pemecahan masalah matematika dan berpikir kreatif siswa tercapai setelah dua kali ujicoba. Pada ujicoba I, ketuntasan klasikal sebesar 63,15\%. Pada ujicoba II, ketuntasan siswa secara klasikal sebesar $87,5 \%$ dan ketercapaian indikator tuntas.

\section{KESIMPULAN DAN SARAN}

Adapun kesimpulan dalam penelitian ini adalah data uji-t kemampuan pemecahan masalah matematis siswa dari tiga sekolah hanya di SMP Negeri 1 Kota Lubuklinggau yang menunjukkan signifikan kurang dari atau sama dengan $61(\mu o \leq 61)$. SMP Negeri 14 Kota Lubuklinggau dan SMP PGRI 3 Lubuklinggau menunjukkan rata-rata kemampuan pemecahan masalah matematis siswa setelah menggunakan LKS Berbasis open-ended secara signifikan lebih dari $61(\mu o>61)$. Dari dua sekolah yang sudah terwakili dapat disimpulkan bahwa implementasi LKS berbasis openended sudah efektif dan dapat digunakan sebagai LKS pendaping dalam proses pembelajaran di kelas. Terutama dalam melatih kemampuan pemecahan masalah siswa melalui kegiatan yang disajikan dengan menekankan masalah-masalah terbuka.

Adapun saran dalam penelitian ini terkait temuan-temuan dan keterbatasan dalam penelitian, yaitu masih adanya siswa yang kesulitan dalam menyelesaikan masalah terbuka pada setiap kegiatan dikarenakan belum terbiasanya siswa dengan soal-soal terbuka pada LKS, sehingga perlu bimbingan dan arahan dalam penyelesainnya. Berdasarkan jawaban hipotesis pada sekolah dengan kategori tinggi, sehingga perlu dilakukan penelitian lanjutan untuk menguji kembali efektivitas LKS berbasis pendekatan open-ended pada sekolah dalam kategori tinggi lainnya. LKS berbasis pendekatan open-ended dapat dijadikan sebagai sumber belajar bagi siswa dan guru sebagai pendukung dalam proses pembelajaran di kelas apalagi untuk sekolah dalam kategori sedang.

\section{DAFTAR PUSTAKA}

Anwar, N., Johar, R., \& Juandi, D. (2015). Pengembangan Perangkat Pembelajaran Berbasis Pendekatan Open-Ended untuk Meningkatkan Kemampuan Berpikir Kreatif Matematis Siswa SMP. Jurnal Didaktik Matematika, 2, 52-63.

Amir, F., M. (2015). Pengaruh Pembelajaran Kontekstual Terhadap Kemampuan Pemecahan Masalah Matematika Siswa Sekolah Dasar. Prosiding Seminar Nasional Pendidikan. Hal 34-41

Arikunto, S. (2010). Prosedur Penelitian Suatu Pendekatan Praktik Edisi Revisi. Jakarta: Rineka Cipta. 
Evalida, A., \& Hasratuddin. (2016). Pengembangan Lembar Kerja Siswa Berbasis Pendekatan Open-Ended untuk Meningkatkan Kemampuan Pemecahan Masalah Matematika dan Berpikir Kreatif Siswa Kelas VIII SMP Berastagi T.A. 2014/2015. Jurnal Inspiratif, 2, 9-19.

Gunawan, A., M. (2013). Statistik untuk Penelitian Pendidikan. Yogyakarta: Pazama Publishing. Kasmawati, Yenti, I. S., \& Zulmardi. (2014). Pengembangan LKS Segitiga dan Segi Empat Berbasis Pendekatan Open-Ended pada Pembelajaran Matematika Kelas VII SMP N 1 Baso. Edusainstika, 1, 40-42.

Lestari, K. E., \& Yudhanegara, M. R. (2015). Penelitian Pendidikan Matematika. Karawang: PT Refika Aditama.

Mayasari, D. (2014). Pengembangan Bahan Ajar dengan Menggunakan Pendekatan Open Ended untuk Meningkatkan Kemampuan Pemecahan Masalah Matematis Siswa SMP Negeri 6 Pematang Siantar. Tesis PPS Unimed. Medan: Tidak Dipublikasikan.

Mina, E. (2006) . Pengaruh Pembelajaran Matematika dengan Pendekatan Open-ended terhadap kemampuan Berpikir Kreatif Matematika Siswa SMA Bandung. Tesis pada PPs UPI. Bandung: Tidak Dipublikasikan.

Mursalin. (2014). Pengembangan Buku Siswa Materi Aritmetika Sosial Berbasis Pembelajaran Model Treffinger untuk Mendukung Kemampuan Berpikir Kreatif Siswa SMP Negeri 19 Malang. Pascasarjana Universitas Negeri Malang.
Mustikasari, Zulkardi, \& Aisyah, N. (2010). Pengembangan Soal-Soal Open-ended Pokok Bahasan Bilangan Pecahan Di Sekolah Menengah Pertama. Jurnal Pendidikan Matematika, 4, 4560.

Puspitasari, A., Lambertus, \& Samparadja, H. (2014). Efektivitas Pendekatan OpenEnded Untuk Meningkatkan Kemampuan Pemecahan Masalah Matematika Siswa Kelas VIII SMP Negeri 13 Kendari. Jurnal Penelitian Pendidikan Matematika, 2, 1-16.

Setiawan \& Harta. (2014). Pengaruh Pendekatan Open-Ended dan Pendekatan Kontekstual Terhadap Kemampuan Pemecahan Masalah dan Sikap Siswa Terhadap Matematika. Jurnal Riset Pendidikan Matematika, 1, 240-256.

Suci, A., A., W., \& Rosyidi, A., H. (2012). Kemampuan Pemecahan Masalah Matematika Siswa Pada Pembelajaran Problem Posing Berkelompok. Jurnal Unesa, 1.

Suyatno. (2009). Menjelajah Pembelajaran Inovatif. Sidoarjo: Mas Media Pustaka.

Tim Pengembang Ilmu Pendidikan UPI. (2009). Ilmu dan aplikasi pendidikan, bagian III: Pendidikan disiplin ilmu. Bandung: PT Imperial Bhakti Utama.

Wijaya, A. (2012). Pendidikan Matematika Realistik "Suatu Alternatif Pendekatan Pembelajaran Matematika". Yogyakarta: Graha Ilmu 